\title{
ISLAMIC AND RELIGIOUS STUDIES Challenges and Opportunities for Twenty-First Century Indonesia
}

\author{
Mark Woodward \\ Department of Religious Studies \\ Center for the Study of Religion and Conflict \\ Arizona State University, USA
}

\begin{abstract}
This paper explores challenges and opportunities for Religious and Islamic Studies in the opening years of the twenty first century. It is especially concerned with relationships between the Indonesian, North American and Global contexts in which the two disciplines are located and the ways in which scholarly discourse can be enriched by trans-national cooperation and discourse. It is argued that Religious Studies should be understood as an academic discourse about religion and must be clearly distinguished from religious discourse internal to and across confessional lines. In a more concrete way, the paper is concerned with the epistemological foundations of the academic study of religion and with the issue of pluralism. It is argued that in today's globalized world pluralism is a fact that cannot be ignored or eliminated. Discussion on what Eck has identified as three dimensions of pluralism, civic, theological and academic.
\end{abstract}

Keywords: Islamic studies, Indonesian studies, religious pluralism.

\section{Introduction}

This paper explores challenges and opportunities for Religious and Islamic Studies in the opening years of the $21^{\text {st }}$ century. I will be especially concerned with relationships between the Indonesian, North American and Global contexts in which the two disciplines are located and the ways in which scholarly discourse can be enriched by transnational cooperation and discourse. Proponents of rationalist 
epistemologies would have us believe that centuries are entirely arbitrary demarcations of the course of history. And yet, there is a very broad, trans-cultural and trans-religious tendency to use them to impose some sort of order on the course of human events and to attribute special significance to the advent on new ones. Universities across the globe use centuries to organize their history and literature curricula. This division reflects a more general intellectual tendency that is evident far beyond the borders of academe. Sometimes the dawn of a new century does actually mark a significant historical turning point. In other cases events are interpreted in ways that make them fit the model. No matter what calendar one refers to, the more zeros there are at the end of a year, the more important it is thought to be. Christians are famous, or notorious, depending on one's perspective, for this sort of thinking. In parts of Europe in $1000 \mathrm{AD}$ some people were so convinced that Christ would return during the year that they did not bother to plant crops in the spring and starved in the winter. A thousand years later, the dawn of the $21^{\text {st }}$ century was greeted with equally intense anticipation. Tragically the events that seem to define at least the first part of the century did not occur until the next September. Islam teaches that Allah will send a "renewer" (mujaddid) to restore the faith to its pristine condition at the beginning of each century of the Muslim calendar. The Iranian Islamic Revolution began in 1979 C.E. which was 1400 A.H. Traditional Javanese historiography is predicated on the assumption that a new kingdom is, or at least should be, established at the beginning of each century on the Javanese calendar. ${ }^{1}$ In his inaugural address U.S. President John F. Kennedy stated that "the torch has been passed to a new generation of leadership born in this century." One could continue almost indefinitely. Centuries are important because we think they are. The dawn of a new century offers an opportunity to reflect on the accomplishments and short comings of the past and to make new and hopefully more productive beginnings.

In reflecting on the challenges and opportunities for Islamic Studies and Religious Studies in the twenty-first century we are, therefore, in good company. In this paper I will describe and reflect upon what I believe to be the two major challenges facing Islamic

\footnotetext{
${ }^{1}$ See M. Ricklefs, Jogjakarta under Sultan Mangkubumi, 1749-1792: A History of the Division of Java (London: Oxford University Press, 1974).
} 
Studies and Religious Studies in the twenty-first century C.E. These reflections are based on close readings of scholarly writing in both discourse and my experience conducting research and teaching in the United States and Indonesia for more than thirty years. I will be concerned with Religious Studies very broadly. If I mention Islam and Christianity more frequently than other religions in this discussion it is because Muslim-Christian conflict looms largest in Indonesia and globally and because I am writing in the Indonesian context. ${ }^{2}$ Similarly, in the case of Islamic Studies I will be especially concerned with the study of Islam in Indonesia for the simple reason that it is the part of the Islamic World with which I am most familiar. To anticipate briefly these challenges are: First, the very basic challenge or defining what the fields are, and equally as important what they are not, or at least what they should not be in the context of a multi-centered global world system. The second is the challenge of pluralism, in its many forms, of which only three; civic or political pluralism; theological pluralism and academic pluralism are considered here. These challenges are, at the same time, opportunities for broadening and enriching the fields.

As academic disciplines Islamic Studies and Religious Studies can be located in any religious, cultural or geographic space. They can be studied in Yogyakarta at the Center for Religious and Cross-Cultural Studies, at Arizona State University in the United States or anywhere else. The only contexts where these disciplines cannot be productively pursued are those in which intellectual discourse is constrained by repressive political, cultural or religious regimes. What is important is not who you are, where you live or what religion you happen to believe in, but how you think about religion. What is more important than anything else to be fair, honest and open to new ideas and opinions. Having said this, the largest challenge and opportunity for Religious and Islamic Studies in the twenty-first century is to be exactly that fair, honest and open to new ideas and opinions. This is not always easy, for any of us, but if we can accomplish this goal, I am certain that we can meet other challenges and that we will all have the opportunity to learn from each other and most importantly that we will have the

\footnotetext{
2 Similar reflections written in a South Asian context would necessarily including Hinduism in the mix. In Srilanka and Burma it would also be necessary to include Theravada Buddhism and the in the Middle East it would, of course, be necessary to include Judaism. China is a different case, because questions of pluralism revolve around relationships between religions and the secular state.
} 
opportunity to help make the world a better place for all of us, and especially our children and grandchildren to live. In confronting this challenge the most important and most difficult thing that we have to do is to overcome old prejudices and stereotypes, some of which are centuries old and some of which our political, and too often, religious leaders are still tied to. In the cases of Religious Studies and Islamic Studies in Indonesian and North American contexts this is the challenge of confronting what Edward Said has called Orientalism and what Hasan Hanafi has called Occidentalism. ${ }^{3}$

\section{Challenges and Opportunities of Definition}

Prior to commencing a discussion of the challenges and opportunities of pluralism, it is essential to clarify exactly what it is that we mean by "Islamic Studies" and "Religious Studies." Questions of definition are themselves among the challenges the fields confront, in part because Religious Studies continues to struggle with issues of its own collective identity and location within the academy. In the broadest sense by "Religious Studies" I mean the academic, as opposed to theological or critical study of religion. "Islamic Studies" is the sub-field of Religious Studies that is concerned with Islam, historical and contemporary Muslim communities. In both cases, the details are far more complex and are often politically as well as intellectually contested. The terms can be used in many ways within particular scholarly and linguistic communities and there can be problems when we try to talk and think about them across languages, histories, cultures and religions. Translating linguistic texts, even simple ones, is always difficult. Translating complex systems of ideas is more difficult and translating ideas about something as important and politically charged as "religion" is more difficult still. It is far more difficult to conceptualize the social sciences or humanities. Across cultural and religious boundaries than it is the "hard" science because values as well as facts are at issue. ${ }^{5}$ It is very clear when people confuse

3 E. Said, Orientalism (New York: Vintage Books, 1979); H. Hanafi, "Pembaruan Wacana Keagamaan: Mulai dari Realita, Baru Teks," in M. Arkoun and Others, Orientalism vis-avis Oksidentalisme (Jakarta: Pustaka Firdaus, 2008), pp. 20-31.

${ }^{4}$ I use the term theological very broadly to refer to religious discourse internal to historically defined religious traditions, and not exclusively to Christian discourse.

${ }^{5}$ Economics is the exception, at least so far as the Muslim world is concerned. But, in the case of economics there are clearly defined and competing paradigms based on 
religion and chemistry and easy to show that there is no Christian, Buddhist or Islamic Christianity. It is far more difficult to determine the ways in religious ideas influence academic discourse about religion. It is also important to make very clear what I do not mean by "Islamic Studies" and "Religious Studies" to lessen the risk of unnecessary and contentious disputations that all too often leave participants talking at cross purposes.

\section{Islamic and Indonesian Studies}

By Islamic Studies I do not mean Orientalism as the term is now commonly understood. I also do not mean ' $\mathrm{Im}$ al-Di $\rightarrow$ or anything like it.6 "Islamic Studies" is not about "how to be a Muslim" or "What Muslims should believe or think." Perhaps the best way of defining it is: "The study of what Muslim communities have thought Islam in various historical, cultural and sectarian contexts" This is very long and I hope that it is clear. This point is especially critical because there are many who understand the term and the discipline confessionally or in terms of simplistic, and often second hand, readings or tellings of Edward Said's Orientalism. Said observes that:

To the west, Asia had once represented silent distance and alienation; Islam was militantly hostile to European Christianity. To overcome such redoubtable constants the Orient needed first [to] be known, then invaded and possessed, then recreated by scholars, soldiers, and judges who disinterred forgotten languages, histories, races, and cultures in order to posit then-beyond the modern Oriental's ken—as the true classical Orient that could be used to judge and rule the modern Orient. ${ }^{7}$

If this is Religious Studies or Islamic studies I do not want anything to do with either. Nor do the vast majority of by Western and Indonesian colleagues. But the world has changed and so has the politics of scholarship.

recognizable and generally speaking explicit assumptions. This is not the case in Religious Studies, where assumptions tend to be more implicit and are often veiled by ambiguous terminology.

${ }^{6}$ I would like to that Ronald Lukens-Bull of the University of North Florida in the United States for the observation that the English term "Islamic Studies" can be translated in this way.

${ }^{7}$ Said, Orientalism, pp. 91-92. 
Dutch colonial scholarship on Indonesian Islam provides a very clear example of how the old Orientalism worked and how pernicious it was. Christian Snouck Hurgronje, clearly the most insightful and knowledgeable colonial scholar in the field, was also, simply put, an intelligence operative. His purpose was to describe Islam in what was then the Netherlands Indies and is now Indonesia to further its political emasculation and to facilitate the strengthening and expansion of Dutch hegemony ${ }^{8}$ In addition to now classic ethnological accounts of Islam and Muslim communities in Sumatra, his most important work was his account of the "Jawi" community in Mecca and the Hadj $j$, Hurgronje disguised himself as a Central Asian Muslim and traveled in cognito to Mecca as much to discern the political orientation of the "Jawi Colony" as to advance scholarship. He also wrote numerous "advisory" reports for the Netherlands Indies Government and advocated vigorous prosecution of the very nearly genocidal war in Ache. ${ }^{9}$ This was clearly scholarship in the service of imperium.

A generation after the publication of Said's magnum opus there are many who are convinced that his observations apply to contemporary "Western" scholars and scholarship as much as they do to colonial scholars of the nineteenth and early twentieth centuries. In Indonesia, and throughout the Muslim world, there are those who maintain that the "Orientalist" tradition continues to dominate the social sciences and humanities and that "Orientalists" and "Orientalism" are a threat to the integrity of local religious, cultural and national identities More extreme proponents of this view describe Islamic Studies and Religious Studies as elements of a program of "Christianisation" and are bitterly critical of Muslim scholars who have studied in the west, sometimes denouncing them as apostates. ${ }^{10}$ To be blunt, this view is simply false.

\footnotetext{
${ }^{8}$ Harry J. Benda, "Christian Snouck Hurgronje and the Foundations of Dutch Islamic Policy in Indonesia," in Continuity and Change in Southeast Asia: Collected Journal Articles of Harry J. Benda (New Haven: Yale University Center for Southeast Asian Studies, 1972), p. 86. See also C. Snouck Hurgronje, Mohammedanism (New York: the Knickerbocker Press, 1916).

${ }_{9}$ C. Snouck Hurgronje, Mekeka in the Latter Part of the Nineteenth Century (Leiden: E. J. Brill, 1931), p. 79.

10 See Panjimas, Vol. 1, No. 12, (May 2007). For an extreme version of this position which associates Religious and Islamic Studies with a Zionist-Crusader conspiracy to subjugate or even to destroy Islam and the Muslim community see, Al-Insan Journal Kajian Islam, Vol. 1, No.1 (2007), especially pp. 131-139. Media Dakwah has consistently engaged in this type of takfiri rhetoric for many years. In the 1990s several issues-
} 
Those who hold to them do so to advance political agendas and/or are guilty of what Roman Catholic moral theologians call "invincible ignorance," a concept that refers to those who cling to untenable propositions regardless of facts and logical arguments deployed against them. Such propositions are frequently phrased in terms that are in principle non-falsifiable, and as such outside the realm of rational discourse. ${ }^{11}$

To paraphrase President Kennedy, a new generation of "Western" scholars, most of us born in the era of post-coloniality, and powerfully affected by the horror and blatant imperialism of the Indo-China Wars, want no part of, and indeed actively oppose, the hegemonic agenda of the Orientalist paradigm. The fact that radical Muslim critiques of contemporary Islamic Studies scholarship are without logical foundation does not, unfortunately, diminish their appeal. Proponents of these views appeal to emotion, not logic.

There are, to be sure, still some old style Orientalists, including Bernard Lewis, who continue to ask the same old wrong questions for the same old wrong reasons. There are also neo-conservative pundits such as Daniel Pipes who seek to breathe new life into the Orientalist paradigm by recasting it in terms of the "Global War on Terrorism," blaming most everything that is wrong with the world on Islam and/or Muslims and denouncing North American critics of Orientalism and Islamaphobia, myself included, as "Jihadi Professors." 12 This is to be

particularly that of January 1993-Nurcholish Madjid was denounced as a Theosophist; an agent of Zionism and its supposed ally, Orientalism; an apostate; an enemy of Islam seeking to destroy it from within; a person who should be "brought to justice by the Islamic community"; a "stranger in the land of Allah"; and a "cancer which must be removed from the body of Islam." These are extremely harsh words, particularly in light of the fact that according to Islamic law, which Media Dakwah promotes, the punishment for apostasy is death.

11 The distinction between falsifiable and non-falsifiable propositions is the basis of that between scientific theories, which are at least potentially falsifiable, and ideologies, which are not. Lewis, Pipes and others operate within ideological discourse systems. On falsifiability as a criteria for evaluating scientific theories see K. Popper, The Logic of Scientific Discovery (New York: Routledge 2002) (1934).

12 B. Lewis, What Went Wrong? the Clash Between Islam and Modernity in the Middle East (New York: Harper Perennial, 2003); D. Pipes, Militant Islam Reaches America (New York: W.W. Norton, 2003). Most of us on Pipes' list consider it an honor to be included. I have argued elsewhere that attempts to attribute the subordinate position of Muslim peoples and countries in the World System are Orientalist fictions masking the military and economic foundations of Western hegemony. See M. Woodward, 
expected because as the historian and philosopher of science Thomas Kuhn has observed, scientific paradigms are strongly associated with communities of scholars, who are rarely inclined to alter their views, even in the face of evidence that it would be appropriate. ${ }^{13}$ At the same time, those who advocate these positions are as guilty to "invincible ignorance" as their Islamist foes. The fact that radical Orientalist critiques of Islam and/or Muslims are without logical foundation does not, unfortunately, diminish their appeal. Proponents of these views appeal to emotion, not logic. Radical Orientalists and Radical Muslim critics of what they believe to be Orientalist tendencies in Western and Indonesian scholarship are two sides of the same tarnished coin.

North American scholars have been engaged in the deconstruction of the Orientalist paradigm for more than two decades. This has involved an intense period of self reflection and criticism and the exposure of the ways in which this paradigm has influenced even seemingly politically neutral scholarship. Orientalist influences are especially apparent in Western studies of Indonesian Islam. Exposes of the Orientalist character of Euro-American scholarship concerning Islam in Indonesia by William Roff and Karel Steenbrink parallel Said's expose of the hegemonic character of Orientalist discourse concerning the central lands of the Islamic world. ${ }^{14}$ Roff observes that there has been:

an extraordinary desire on the part of Western social science observers to diminish, conceptually, the place and role of the religion and culture of Islam, now and in the past, in Southeast Asian societies.

He attributes this tendency in part to the desire of colonial powers to vanquish their Muslim subjects by locating "greatness" in a classical

\footnotetext{
"Modernity and the Disenchantment of Life: A Muslim Christian Contrast," in, J. Meuleman (ed.), Islam in the Era of Globalization. Muslim Attitudes Towards Modernity and Identity (London: Routledge Cruzon, 2002), pp. 111-142.

${ }_{13}$ T. Kuhn, The Structure of Scientific Revolutions (Chicago: University of Chicago Press, 1996), pp. 176-177.

${ }^{14}$ See W. Roff, "Islam Obscured? Some Reflections on Studies of Islam and Society in Southeast Asia," Archipel, 29, No. 1 (1985): pp. 7-34; K. Steenbrink, Dutch Colonialism and Indonesian Islam: Contacts and Conflicts 1596-1950 (Amsterdam and Atlanta: Editions Rodopi B.V., 1993), p. 50.
} 
Hindu/Buddhist past and depravity in a corrupt Islamic present. ${ }^{15} \mathrm{~A}$ related factor is the often simplistic and legalistic understanding of Islam that has been used in the evaluation of Southeast Asian religious systems. ${ }^{16}$ Steenbrink notes that Dutch "Indologie" was influenced by a colonial concern bordering on obsession with the legal dimension of Islam. ${ }^{17}$ While this concern is understandable given the colonial context in which Orientalism was located, it contributed to the formulation of a highly distorted understanding of Islam as a religion, and of the role of Islam in the religious lives of Indonesians. It is based in part on the completely unwarranted assumption that Saudi Arabian Wahhabi Islam is, as it claims to be, the "genuine" Islam and a standard against which other "Islam's" can be judged. It is at once ironic and tragic that Islamist extremists and Orientalist extremists share a common understanding what the "genuine" Islam is.

The persistence of Orientalist themes in Euro-American Indonesian Studies is due in large measure to the influence Clifford Geertz, whose renown for theoretical contributions to Anthropology and other human sciences is well known and well deserved. Geertz's theoretical acumen was, unfortunately, combined with a simplistic and inaccurate understanding of Islam and its role in the lives of Javanese and other Indonesians. His understanding of Islam in Java was based largely on Hurgronje's. ${ }^{18}$ Geertz cites Hurgronje's statement that:

...the building of Islam is still mainly supported by the central pillar, the confession that there is no god but Allah and that Muhammad is the messenger of Allah, [however] this pillar is surrounded with a medley of ornamental work quite unsuited to it which is a profanation of its lofty simplicity.

\footnotetext{
15 The "depravity" and "decadence" of Muslim cultures has been a prominent theme is Western anti-Islamic polemics since the Middle Ages. On this theme see M. Woodward, Jalan Baru Islam; Memetakan Paradigm Mutakhir Islam Indonesia (Jakarta: Mizan, 1998).

16 The notion that "Islam" can be defined on the basis of legalistic or behavior criteria is normative and as such should not figure in Religious Studies discourse.

${ }^{17}$ Steenbrink, Dutch Colonialism, pp. 90-91.

18 M. Woodward, Islam Jawa Kesalehan Normatif Versus Kebatinan (Yogyakarta: LKiS, 1999, fourth edition 2008); and idem., Jalan Baru Islam.
} 
With approval, commenting that: "his simile would have applied even more aptly to Java." 19 In part because of his reliance on Hurgronje's mode of analysis, Geertz's interpretations of Islam in Java, and Indonesia more broadly are simply wrong. His description of the Javanese Kyai and Pesantren as being only marginally Islamic is so deeply flawed that I have often wondered if he every spoke with a Kyai or visited a Pesantren. Geertz's influence was so pervasive that most of us who were graduate students focusing on Indonesia in the 1970 were discouraged from pursuing serious study of Islam. Mitsuo Nakamura and I shared similar experiences when we actually arrived in Yogyakarta. I was surprised to discover that the state ceremonies of the Yogyakarta court were Islamic. Nakamura observes that: "While I was living amidst Javanese Muslims I gradually started to feel and realize that there is nothing peculiar for a Javanese to be a pious Muslim." ${ }^{20}$ Looking back on it, this was a very strange state of affairs. Nakamura and I were Ph.D candidates in what were at the time two of the premiere Southeast Asian Studies programs in the United States: Cornell University and the University of Illinois. We had both obtained prestigious fellowships to support our dissertation research projects and neither us had the slightest inclination that Javanese really are Muslims. That would not happen today.

In one of his later works, which offers a retrospective commentary on more than four decades on research and reflection on Indonesian society and religion, Geertz argued that the emergence of a new, Islamcentered paradigm in Indonesian studies in the 1980s can be attributed to the influence of the Indonesian government's program of encouraging religious tolerance and discouraging the Islamic rhetoric of apostasy and unbelief in scholarly characterizations of Islam. ${ }^{21}$ This is torturous, and I must add self serving, logic. It suggests that an

${ }^{19}$ C. Geertz, The Religion of Java (Glencoe: The Free Press, 1960), p. 124; C. Snouck Hurgronje, The Achenese (Leiden: E.J. Brill, 1906), pp. 313. I have spent virtually my entire career arguing against this interpretation of Islam in Java and elsewhere in Indonesia. For expanded versions of articles published over the past two decades see M. Woodward, Islam, Nationality and Culture (Yogyakarta: Universitas Islam Negeri Sunan Kalijaga Press, forthcoming).

20 M. Nakamura, The Cresent Arises Over the Banyan Tree (Yogyakarta: Gadjah Mada University Press, 1983), pp. 182-83.

21 C. Geertz, After the Fact: Two Countries, Four Decades, One Anthropologist (Cambridge: Harvard University Press, 1995), pp. 56-57. 
entire generation of Indonesian and Western scholars had fallen so deeply under Suharto's spell that we could not tell the difference between scientific analysis and New Order propaganda!22 Suharto was very powerful, but not that powerful. Geertz never acknowledged the works of those whose interpretations Indonesia or Islam differed from his own as scholarly achievements, or as reflecting "on the ground" realities. At a meeting sponsored by the US Indonesia Society in 1998, at which Robert Hefner, Nurcholish Madjid and I were all present, he stated that he had said everything that needed to be said about Islam in Indonesia in the 1950s and that nothing had changed. Out of respect for a senior colleague Madjid, Hefner and I chose not to reply - or perhaps it was because of the sheer audacity of his statement - I don't really know and don't think that I ever will.

Geertz's rearguard defenses notwithstanding, Islamic Studies, or at least Islamic Studies as conducted in and about Indonesia, has changed fundamentally since the beginning of the paradigm shift in the 1980s. It is now, at least in my view, better suited to the task of understanding the variety of Indonesian Islam's than it has ever been. The Old Orientalism has been relegated to the dust bin of history. ${ }^{23}$ Fully two generations of scholars committed to the view that Islam must be taken seriously in the analysis of Indonesian cultures, literatures, symbolism politics and other aspects of individual and collective experience have come to maturity. A third generation are now making their way onto the scholarly stage. Islamic Studies in Indonesia has returned to a "normal science" mode of discourse. Today it can hardly be called a "Western" discipline as Indonesian, Japanese, Malaysian and Singaporean scholars play leading roles. The younger generation of Western scholars are far better suited to the task than those of us who came of age in the 1970s and 1980s because they have not had to play

\footnotetext{
22 The list of scholarly luminaries who would have been included on this list is too long to recount here. By virtue of the ways in which they have described Islam in Indonesia Western scholars would include John Bowen, Nancy Florida, Anna Gade, Robert and Nancy Smith Heffner and Ronald Lukens-Bull. Indonesian scholars would have to be included are Tuafik Abdullah, Dwi Atmaja, Azyurmadi Azra, Nurcholish Madjid, Abdurahman Masud, Amien Rais and Inayah Rochmaniyah. There are many others.

23 This does not mean that works produced within this paradigm are without value. Many contain enormous amounts of data that could not possibly be collected today because of scale of change that has taken place in Indonesia over the last century. Rather, the information they include must be carefully scrutinized, but can be used in the construction of analyses quite different from those the authors intended.
} 
"catch up," recognizing the importance of Islam only when in the final stages of writing Doctoral Dissertations. Many are fluent in Arabic, as, of course, are many Indonesian scholars this is a vitally important research tool that most of us of the now "older generation" never acquired. In closing this discussion I would say that nearly a decade into the Twenty-first Century, the prospects for the study of Islam in Indonesia and elsewhere in Southeast Asia are very bright indeed.

There are, however, challenges facing Islamic Studies in Indonesia that will continue well into this century. One set of challenges involve substantive issues, another barriers to scholarly communications. In Indonesia's new era of freedom of speech and religious freedom, it is difficult to keep abreast of emerging developments in such an enormous and diverse country. Regional and local developments that escape the attention of national media are especially challenging to follow. They are also, perhaps the most important, because they are the ones that touch people's lives directly. Progress in the field requires expanding and sustaining intellectual contact and co-operation between Indonesian and non-Indonesian scholars. This challenge is as much financial as it is intellectual. Funding for academic research is never adequate. It is not realistic to hope that the future will be, at least in this respect, any brighter than the present. Research in the Human Sciences is among the last things to be added to national budgets and usually among the first things to be cut when economic times are hard. Given the mess that US policies have made of the world economy, prospects for the short and mid-range futures are not bright.

The continued expansion of electronic communication and especially expansion of its capacity as a means for disseminating scholarly works presents opportunities the extent of which we are only now beginning to realize. The challenge is that of how to make these tools more generally available, especially in the developing world. It is to bridge the digital divide so that all parties to scholarly discourse have equal access to these resources. Language is also a challenge. While many works by Western scholars are now available in Indonesian translation, the reverse is not the case. Very few Western Islamic Studies and Religious Studies scholars can read Indonesian. And very few works by Indonesian scholars are translated. This means that Indonesian scholarship does not receive nearly the international attention it deserves. Given the costs of translation and publication in 
the developed the world the only realistic strategy for ameliorating this difficult is the expansion of English language publication in Indonesia.

\section{Religious Studies}

Religious Studies is an academic discipline that developed in Europe and North America over the past century, and which has now expanded to many other parts of the world. It is also sometimes called "Comparative Religions" or in German Religions Wissenschaft, which translates, The Science of Religions. Perhaps the best way to translate Religious Studies into Indonesian is Pelajaran Lintas Agama or translating back into English "Studies across Religions." It is, or at least tries to be, fair and balanced in the study of the many religions that one encounters in world history and the modern world. It is not Ilm al-Kalarz, or Theology or Dharma or any of the terms that the various religions would use to describe discourse about religion internal to particular traditions. We must be very careful to avoid this impression because the two concepts are easily and often confused, even in academic circles. ${ }^{24} \mathrm{I}$ can say, that having taught "Comparative Religions" and "World Religions" for many years in the United States, Indonesia and Singapore that one finds the same sort of problems among Americans about what it is that we mean, and who we are, that one sometimes finds in Indonesia. Some students, and sometimes their parents, hope or fear that we will teach about a particular religion in religious ways. In both the US and Indonesia there are organized pressure groups that either oppose the academic study of religion altogether, or alternatively want to use it and/or other aspects of the curriculum to promote particular religious agendas. Very few Religious Studies scholars bend to these pressures. ${ }^{25} \mathrm{I}$, and most others in the field, look instead at how different religions face common problems and try to answer common questions, without privileging any one answer or any one religion. In the more than two decades that I have taught Religious Studies classes, I have never seen a student loose her or his faith from exposure to "other" religions.

\footnotetext{
${ }^{24}$ Many Anthropologists, for example, are suspicious of Religious Studies scholarship because they associate it, incorrectly, with Christian missions.

25 Such forces present far more serious problems in countries where religion is highly politically salient than they do in Europe, the United States, Australia and New Zealand where academic discourse is more heavily shielded from political pressure by constitutional and other legal guarantees.
} 
Religious Studies is defined more by its subject matter - religionthan by a coherent body of theory and method. Some Religious Studies scholars devote themselves to the study of ancient or contemporary religious texts, others to religion as it is lived and experienced in the flow of life. Still others, myself included, tack back and forth between the two, seeking to combine textual and ethnographic analysis in works that can be characterized as disciplinary hybridities. While an increasing number of scholars in the field hold advanced degrees in Religious Studies, others are trained in related disciplines. Anthropology, History, Philosophy, Psychology, and Sociology are perhaps the most common. Others have degrees in interdisciplinary Area Studies fields.

What unites Religious Studies as a field is commitment to the view that while religion is shaped by the cultural, social, political, economic and other contexts within which it is located that it is also, like language, a human universal and that in some sense it exists independently of the contexts in which it is located. Questions concerning the ontological status of religion, and what the methodological implications of solutions to this query are figure prominently in contemporary Religious Studies discourse. There is, as of now, no consensus concerning these matters, nor is it likely that one will emerge because of the central role that religion plays in the lives, as well as the works, of many scholars in the field. ${ }^{26}$ Two of the important challenges the field faces are those of the religious status of the analytic categories it employs and how scholars should position themselves methodologically with respect to questions concerning the ontological status of religion.

It is now widely recognized that many of the analytic categories commonly employed by Religious Studies scholars are historically tied to Christian, and more specifically Protestant theology. This does not mean that Religious Studies has a Christian agenda, but only that many of the categories and concepts commonly employed in scholarly discourse are historically derived from those of Christian discourse. The discipline is currently undergoing a period of intensive self

\footnotetext{
${ }^{26}$ Here it is important to note that not having personal religious beliefs can be as important as having them. Scholars who are personally committed to the view that religion is an entirely human phenomena are far less likely to opt for analytic approaches that allow for even the possibility of the reality of the transcendent that those with personal religious commitments.
} 
criticism in which discussions of what Farid Alatas called the "intellectual Christianization of Religions" are of central importance. ${ }^{27}$ It is essential to note here that this does not mean that the use of these concepts is a convert attempt to promote Protestant Christianity at the expense of other religions. Nothing could be further from the truth. Viewed from the perspective of the Philosophy of Science, the religious origins of a concept are of no consequence for the evaluation of its analytic utility. My use of the concept of "invincible ignorance" is an example. There are two important points: First, the Roman Catholic origins of the concept do not imply that its use in non-confessional discourse about religion indicates a commitment to a Roman Catholic religious agenda. Second, it helps to explain an attitude or psychological orientation that exists among people of many religions, and one might add, among some people who have no religion. The fact that concepts that were originally religious can be desacralized and universalized has important implications for the issue of academic pluralism that will be discussed later in this paper.

Questions concerning the ontological status of religion are of central importance for what can be called "trans-confessional religious thought." One of the most frequently discussed, and most contentious, issues in this discourse is Historian of Religions Mircea Eliade's use of the concept "the sacred." 28 His writings on the subject can be, and are, read in two ways. Eliade can be understood to mean that the concept of the sacred is a universal feature of religion, which can be located across time, space and religions. It can also be, and often is seen by critics and supporters alike as a claim that there is a single transcen-

${ }^{27}$ F. Alatas, "Contemporary Muslim Revival: The Case of 'Protestant' Islam," The Muslim World, Vol. 97 (July 2007). For discussions of the tropes of Protestant theology in Religious Studies and current attempts to disclose and dislodge them see: R. King, Orientalism and Religion. Post Colonial Theory and the Mystic East (London: Routledge, 1999); Timothy Fitzgerald, The Ideology of Religious Studies (Oxford: Oxford University Press, 2000): Authur McCalla, "When is History not History?," in Historical Reflections, 20 (1994), pp. 435-52; Russell McCutchen, Manufacturing Religion; the Discourse on Sui Generis Religion and the Politics of Nostalgia (Oxford: Oxford University Press, 1997); Samuel Preus, Explaining Religion: Criticism and Theory from Bodin to Freud (New Haven: Yale University Press, 1987); Tomoko Masuzawa, The Invention of World Religions (Chicago: University of Chicago Press, 2005); and Donald Wieber, The Politics of Religious Studies (New York: Palgrave, 1999).

28 M. Eliade, the Myth of Eternal Return or Cosmos and History (Princeton: Princeton University Press, 1954). 
dental reality that underlies religious diversity. Secular scholars often mention Eliade's transcendentalism as a reason for disregarding very nearly the entirety of his work. Timothy Fitzgerald, for example, generally discounts Eliade's contributions to scholarly discourse about religion and describes his use of the concept of the "sacred" as: "theological transcendentalism." 29 Daniel Wiebe presents a nearly identical critique, stating that:

.... the object of Eliade's creative hermeneutic is not to provide us with knowledge about religions or even the values held by a given religious community, but rather to recover the abandoned transcendental values and meanings once provided to their devotees by those traditions. ${ }^{30}$

These and other, similar, critiques are relevant only for debates concerning the nature and possibility of trans-confessional religious thought. If one looks to Eliade's writings in search of analytic tools to understand a particular class of religious phenomena, they are strikingly less relevant. I have, for example, argued elsewhere that regardless of its location in Sociological and Religious discourse, Eliade's observation concerning the "repetition of archetypes" is an important tool for understanding the role of sacred geography in premodern states in Indonesia and elsewhere in Southeast Asia. ${ }^{31}$

Similarly divergent views are apparent concerning the methodological approach that Sociologist Peter Berger terms "methodological atheism." 32 After Berger introduced the term in the mid 1960's it rapidly became the dominant methodological approach in all but the most overtly theological Religious Studies circles. This requires some explanation. Berger is prone to the use of provocative language. By" methodological atheism" he does not mean "atheism," as the term is commonly used, (meaning the belief that there are no transcendental realities), as a way of understanding religion. Rather, he means that

\footnotetext{
${ }^{29}$ Fitzgerald, The Ideology of Religious Studies, p. 12.

30 Wieber, The Politics of Religious Studies, p. 60.

31 M. Woodward, "Order and Meaning in the Yogyakarta Kraton," in S. Russell and L. Aragon (eds.), Structuralism's Transformations; Order and Revision in Indonesian and Malaysian Societies (Tempe: ASU PSEAS Monograph Series, 2000), pp 235-280. In the remainder of this paper I will use the term Sociology very broadly to refer to works located in the various Human Science disciplines.

32 P. Berger, The Sacred Canopy: Elements of a Sociological Theory of Religion (Garden City, NY: Doubleday, 1967); Idem, Rumor of Angels (Garden City, NY: Doubleday, 1970).
} 
when we describe and seek to explain religious phenomena it should be without reference to transcendentalism. For example, if we seek to explain the importance of the veneration of saints in Islam as practiced in Jambi, we should appeal to some combination of sociological, historical and even to elements of Muslim doctrine and theology, but not to the putative ontological status of the saints themselves. Berger's methodological imperative was in part a response to religious responses to the use of social science methodologies in the study of religion, which prompted some religious thinkers to claim that religion can only be explained "in its own terms." Such an explanation would be a tautology, an explanation of a phenomenon in terms of itself. This is in keeping with the well established position in the Philosophy of Science that tautologies are not explanations. To return to our example of Muslim saints in Jambi-I would not be surprised to hear that some local Muslims say that "saints are venerated because they are saints." 33 This is an entirely reasonable statement with in a locally defined Muslim discourse system but is not a satisfactory explanation. I prefer the term "religious neutrality" to Berger's "methodological atheism" for two reasons. First because it requires the analyst to disavow any concern with the truth claims of religious phenomena rather than operating with the assumption that they are necessarily invalid. The second is that it is less likely to provoke misunderstanding and unnecessary controversy when used in social and political contexts where atheism is unacceptable.

There are some scholars who question Berger's methodological position. They note that sociologist Robert Bellah and others have called for, but have never actually developed, a means for integrating religious and sociological thought. ${ }^{34}$ These scholars seek to realize this goal by incorporating what can be called "transcendental variables" into social scientific analytic equations. Douglas Porpora argues in favor of a posture that "remains open to a consideration of supernatural realities [but] neither asserts nor precludes them." ${ }^{35}$ In a

33 I have often encountered statements like this in Java, Lombok, Singapore and Malaysia where I have done research on local Muslim saint veneration.

${ }^{34}$ R. Bellah, Beyond Belief: Essays on Religion in a Post-Traditional World (NY: Harper \& Row, 1970).

35 D. Porpora, "Methodological Atheism, Methodological Agnosticism and Religious Experience," Journal for the Theory of Social Behavior, 36 (2006): pp. 57-75. 
similar vein Stan Gaede observes that: "if there are signals of transcendence, then the naturalistic framework is itself flawed and not an adequate base from which to pursue truth, sociological or otherwise...." He then asks, "Would it not make more sense, if one believes in a transcendent reality and if one feels that there are good reasons for such a belief, to develop a framework for doing sociology that includes a faith component?"36

Proponents of this position often reference William James' classic, The Varieties of Religious Experience, as an example of the scientific investigation of transcendent realities in much the same way that secular scholars reference Durkheim. ${ }^{37}$ The secularist response is that religious experience cannot be considered in sociological analysis because we lack the means to observe or study it empirically. ${ }^{38}$ Curiously, discussions of Eliade, whose oblique references to transcendent realities have been the subject of much of the secularist critique of Religious Studies are largely absent from this discourse. It is likely that the reason for this omission is that Gaede, Porpora and others parties to these discussions are arguing for an explicit consideration of "transcendental variables" in sociological analysis. ${ }^{39}$ Their position is that the secular Sociology of Religion advocated by Berger, and most others in the field, is less than objective, and indeed biased, because it excludes them. These scholars are unwilling to accept the "two staged" process advocated by Berger and others a who maintain that sociological analysis conducted in a naturalist or secularist mode can be employed as an input for theological reflection. It is clear that their personal religious commitments preclude this compromise. ${ }^{40}$

\footnotetext{
36 S. Gaede, "Review Symposium: Peter L. Berger's 'The Heretical Imperative'," Journal for the Scientific Study of Religion, Vol. 20 (1981): pp.181-185.

${ }^{37}$ William James, Varieties of Religious Experience (New York: Collier, 1902; 1961).

38 D. Yamane, "Narrative and Religious Experience," Sociology of Religion, 61 (2000): pp. 171-189.

${ }^{39}$ In this discussion I will use the term Sociology broadly to include the social sciences in a more general sense.

40 See also M. Jantzrace, "For an Engaged Reading: William James and the Varieties of Postmodern Religious Experience," in Jeremy Carrette (ed.), William James and the Varieties of Religious Experience: A Centenary Celebration (London: Routledge, 2005), pp. 97-105; D. Lamberth, "Conclusion: Experience and the Value of Religion - Overview and Analysis," in idem., pp. 235-246; M. Poloma, "The Sociological Context of
} 
While many religiously committed scholars will consider the call for the integration of social and religious thought a refreshing development the approach advocated by "Religious Sociologists" is deeply flawed for two reasons. The first is that it resurrects the $19^{\text {th }}$ century "God of the gaps" problem. The second is that in their calls for the inclusion of religious variables in Sociological analysis they are speaking exclusively of Christian variables. There is no justification for this position other than that of Christian apologetics, a view of the science of Sociology that adherents of other religions will find impossible to accept. To accede to this demand would be to make the worst fears of Muslim critics of Orientalism realities. A related is issue of is that of who is qualified to discern these "signals of transcendence." Some Buddhists, for example, are likely to see karma at work in the crisis of the late 1990s that led to the fall of Indonesia's second president Suharto. Muslims are most likely to see takdir. How we to determine which of these principles should be included in a "Religious Sociology of Reformasi"? There is no principled answer to this question so we are best served by avoiding it.

In considering this approach to the Social Sciences it is, I think, informative to reflect on the disastrous consequences of a similar approach to the natural sciences common in Europe several centuries ago, the consequences of which continue to reverberate through Western thought and popular religion. The great natural scientists of the seventeenth century, Kepler, Galileo and Newton among them, were deeply religious men. They understood science to be a way of knowing God as well as nature. Natural law was understood as evidence for the divine plan of creation. Newton in particular can be counted as being among the fathers of what came to be known as Natural Theology as much as of Natural Science. Natural Theology distinguishes between the "Book of God" and the "Book of Nature," both of which are provide source materials for theological speculation. Natural Theology continued to be an important tradition in Christian

Religious Experience," in Ralph W. Hood, Jr. (ed.), Handbook of Religious Experience (Birmingham: 1995), pp. 161-182; S. Post, Human Nature and the Freedom of Public Religious Expression (Notre Dame: University of Notre Dame Press, 2003); and C. Smith, "Why Christianity Works: An Emotions-Focused Phenomenological Account," Sociology of Religion, Vol. 68 (2007): pp. 65-178. 
thought throughout the nineteenth century, particularly in England. ${ }^{41}$ Indeed, the first decades of the century came to be known as the era of the "Holy Alliance" between science and religion. Practitioners of Natural Theology included members of the clergy as well as lay specialists in the natural sciences. They hoped to find signs of God in nature and to reconcile the findings of science with Biblical narrative. As late as 1865 the British Royal Society declared that:

We conceive that it is impossible for the Word of God, as written in the book of nature, and God's word written in Holy Scripture, to contradict one another, however much they may appear to differ. ${ }^{42}$

While Biblical, Qur'anic and other basic scriptures are unchanging, fixed texts; the "Book of Nature" has been continually updated and revised. This gives rise to a continuing theological crisis known as the "God of the gaps" problem. Simply put Natural Theology reserves for God only that which cannot be explained by science. The insistence of the Church that science and religion yield identical interpretations of the natural world contributed to a religious crisis which began with Galileo and Copernicus and that had implications beyond the narrow confines of academic theology. ${ }^{43}$ It called into question the veracity of Biblical cosmology and narrative which were the linchpins of the traditional Christian world view and faith. Polanyi and Prosch observe that for religion to be socially validated, the narratives on which it is

\footnotetext{
${ }^{41}$ For a discussion of the beginnings of Natural Theology in England see J. Gascoigne, Cambridge in the Age of the Enlightenment: Science, Religion and Politics from the Restoration to the French Revolution (Cambridge: Cambridge University Press, 1989). In the United States what is called "Creation Science" is a contemporary form of Natural Theology It is a "pseudo-science" popular among Christians committed to a literalist understanding of the Biblical text. While most religions confront this problem to some extent it is particularly acute in variants of Christianity predicated on a literal reading of Biblical narrative. I have argued elsewhere, See Woodward, "Modernity and the Disenchantment of Life," it is less acute in Islam, because the Qur'an, unlike the Bible is not structured as a universal history, beginning with the origins of the universe and concluding with the end of time.

${ }^{42}$ Cited in Gascoigne, Cambridge in the Age of the Enlightenment, p. 307.

${ }^{43}$ For a summary discussion of the role of theology in pre-enlightenment European worldviews see Thomas Kuhn, The Copernican Revolution. Planetary Astronomy in the Development of Western Thought (Cambridge: Harvard University Press, 1957), pp. 100133.
} 
founded must be at least plausible. ${ }^{44}$ By demonstrating that the traditional cosmology order was not merely implausible--but simply false, questions were also raised about the church's soteriological teachings such as grace, redemption and salvation. Because of the problem of falsification Natural Theologians have always been forced to play "catch up" in ever more complex ways. With the demise of Biblical astronomy, Christian thinkers turned increasing to biology for signs of Gods purpose and design in the universe. At the beginning of the nineteenth century this strategy proved plausible and even productive because biology was believed to point towards a nature so complex and regular that it could only have come to being through divine design. Darwin's theory of natural selection lead to the demise of Natural Theology as a serious intellectual enterprise not so much because he demonstrated the implausibility of Biblical accounts of creation, but because his theory is based on the assumption that there is no inherent, divinely instituted design or order in the natural world. The idea of the transmutation or the development of one species from another was common in the decades preceding Darwin's publication of On the Origin of Species by Means of Natural Selection. ${ }^{45}$

From a strictly scientific perspective Darwin's work can be understood as a contribution to the development of a previously existing discourse. In a larger, cultural and religious sense it broke the bounds of the existing intellectual and religious paradigm which governed scientific and theological inquiry in nineteenth century Britain because, without stating so explicitly if falsified the prevailing view of the divine design of creation There were, and continue to be, attempts to salvage Natural Theology from the intellectual wreckage wrought by advances in the natural sciences. These are of two general types. One is based on the supposed inability of science to explain certain classes of natural, and according to "Religious Sociologists" social phenomena; the other on attempts to show that Biblical narrative does not contradict the principles of science. Some works combine both approaches. All of them have proved to be bad science,

44 Michael Polanyi and Harry Prosch, Meaning (Chicago: The University of Chicago Press, 1975), pp. 158-160.

45 For a discussion of scientific and theological debates concerning the species problem in the mid-nineteenth century see Pietro Corsi, Science and Religion. Baden Powell and the Anglican Debate, 1800-1860 (Cambridge: Cambridge University Press, 1988), pp. 227-286. 
and because of the claims that Natural Theology makes concerning the compatibility of the Book of Nature and the Book of God, equally bad theology. Theologians were forced into a combination of apologetic and/or defensive positions, struggling to find a place for God in the ever expanding universe. Scientists could safely ignore God, at least as far as their professional lives were concerned. ${ }^{46}$

In the West the cost of establishing the independence of science and religion was enormous. The ways in which this was achieved alienated scientific and religious communities. It contributed significantly to the almost total secularization of Western European societies and to seemingly irresolvable political divisions and "Culture Wars" in the United States. Simply incorporating transcendental variables into sociological analysis would probably have similar results, recreating the God of the gaps problem as continued advances in Sociology render any existing synthesis impossible to maintain over time. Humanity would be better served by greater attention to the works of Schleiermacher and other theologians who were aware of and sought to circumvent the "God of the gaps" problem. This understanding of Christian theology not only allows for free scientific enquiry, including sociological enquiry, it also establishes a philosophical foundation for religious pluralism. Taken seriously it requires that all religions be placed on an equal footing with respect to the human and natural sciences.

At the dawn of the nineteenth century the German philosopher and Protestant Christian theologian Friedreich Schleiermacher described the goal of modern theology as the quest for:

$\ldots$ an eternal covenant between the living Christian faith and an independent and freely working science, a covenant by the terms of which science is not hindered and faith not excluded. ${ }^{47}$

\footnotetext{
${ }^{46}$ For examples of late nineteenth century attempts to find some place for God in Darwin's understanding of the evolution of life see Baden Powell, B. H., Creation and its Records; A Brief Statement of Christian Belief with Reference to Modern Facts and Ancient Scripture (London: Hodder and Stoughton, 1886). Baden-Powell argued that because science could not explain the origins of organic from inorganic chemicals; the hand of the creator was visible at least at the point of the origin of life, if not in its development. Subsequent advances in the science of Biochemistry showed this argument to be invalid.

47 Translation in C. Welch, Protestant Thought in the Nineteenth Century (New Haven and London: Yale University Press, 1972), p. 59.
} 
Schleiermacher was the founder of the hermeneutical tradition which continues to be among the primary methodologies of modern Christian theology, and the secular humanities including Religious Studies. He devised hermeneutics to salvage Christianity from the intellectual insolvency of Protestant Biblical Literalism that was the product of the scientific advances of the previous century. Schleiermacher's mode of textual exegesis and religious reasoning focuses on subjective understanding rather than literal reading of scripture. Schleiermacher articulated two ways of knowing or encountering textual materials: a grammatical mode which examines the precise literal meaning of a text and a subjective feeling of its ultimate significance. Hodges characterizes Schleiermacher's hermeneutics as follows:

.... he finds that the understanding of a literary whole has two aspects, both necessary and co-ordinate in status, but different in aim and method, viz. grammatical and psychological understanding. The aim of grammatical understanding is to remove ambiguities in, and to wring the last drop of meaning from the words and phrases which constitute the outward appearance of the work. The aim of psychological understanding is to go beyond this outward appearance to the inner form, the living principle or idea in the author's mind, of which the written text is the expression. ${ }^{48}$

Defining religious truth in this way avoids potential conflicts with both the natural and social sciences. It also motivates appreciation of the truth claims of non-Christian religions and lays the ground work for trans-confessional religious thought. Schleiermacher held that the religious feeling or perception could be located in diverse historical contexts and traditions and that the true meaning of religion could be discovered only through the examination of the totality of its manifestations. His views resonate with those of Sufis who arrived at much the same conclusion many centuries earlier. ${ }^{49} \mathrm{It}$ is in this sense that he contributed to the development of Religious Studies that is perhaps of even greater importance today than in was at the time,

\footnotetext{
${ }^{48}$ H. Hodges, the Philosophy, of Wilhem Dilthey (Westport: Greenwood Press 1952), p. 17.

49 See W. Chittick, The Sufi Path of Knowledge: Ibn al-Arabi's Metaphysics of Imagination (Albany: State University of New York Press, 1989) and R. Nicholson, the Mystics of Islam: An Introduction to Sufism (London: Routledge and Paul, 1975).
} 
more than two centuries ago when he lived and wrote. In 1799 he argued that:

Would you then understand it as it really exists and displays itself, would you comprehend it as an endlessly progressive work of the Spirit that reveals himself in human history, you must abandon the vain and foolish wish that there should only be one religion; you must lay aside all repugnance to its multiplicity; as candidly as possible you must approach everything that has ever, in the changing shape of humanity been developed in its advancing career, from the ever fruitful bosom of the spiritual life. ${ }^{50}$

In the conclusion to his classic study of Nuer religion, E. E. Evans-Pritchard observed that:

Nuer religion is ultimately an interior state. This state is externalized in rites which we can observe, but their meaning depends finally on an awareness of God and that men are dependent on him and must be resigned to his will. At this point the theologian takes over from the anthropologist. ${ }^{51}$

In the 1950s when Evans-Pritchard made these observations, the Nuer had little, if any, voice in the scholarly discussion of their culture and religion. The world has changed enormously since then. Today, social scientists can ill afford to ignore the challenges of analytic works rooted in religious paradigms. In my view the social scientist cannot become the theologian, and the distinction between the two must be maintained for the health of both modes of inquiry, but neither can the social scientist ignore the theologian. There are two reasons for this. If we are to take Schleiermacher's dictum concerning the equivalency of religions as inputs for higher level theological discourse, the interface between religious and social science scholarship cannot be limited to a single religious tradition, as would appear to be the case in the works of the "religious Sociologist" discussed earlier. The second is that in societies like Indonesia, where religion and religious truth claims are taken seriously much that is of great value for Sociological analysis is, and will be to continue to be, written within confessional religious paradigms. These materials can be no more easily ignored, but must be

${ }^{50}$ F. Schleiermacher, On Religion: Speeches to Its Cultured Despisers (1799), transl. by John Oman (Louisville: Westminster John Knox Press, 1994), p. 214.

${ }^{51}$ E. Evans-Pritchard, Nuer Religion (London: Oxford University Press, 1956), p. 322. 
treated with the same caveats, as those written from Orientalist perspectives.

\section{Challenges and Opportunities of Pluralism}

James Spickard has described the struggle between religious universalism and particularism as "the theological battle of our times."52 The challenge of pluralism figures prominently in both academic and political discourse concerning the role of religion in public life in the twenty-first century. The term pluralism has been, and will undoubtedly continue be, used in diverse ways. It is often used to refer to social conditions in which there is a plurality of world views in conjunction with the absence of consensus concerning the ways in which they should be evaluated and acted upon. This leads to a political environment in which no single world view occupies a hegemonic position. ${ }^{53}$ There are many varieties of pluralism: ethnic, ideological, political, philosophical and religious pluralisms being among the most salient. Of these religious pluralisms is perhaps the most complex and problematical because religions typically make universalist claims about the most basic human issues, including the origins and ultimate fate of the cosmos and those who inhabit it, as well as moral and ethnical conduction. Compromise or consensus on these issues is, at best, difficult to achieve.

In the remainder of this paper I will be concerned with challenges arising from the fact of religious pluralism, in a narrow sense of the term, and the ways in which Islamic Studies and Religious Studies can be employed to understand them. ${ }^{54}$

There are two basic types of religious pluralism: internal pluralism and external. By internal pluralism I mean that with in every religion there are different modes of understanding religious truth and acting in religious ways. At least in the case of major "World Religions" there are no exceptions to this rule. By external pluralism I mean the fact

52 J. Spickard, "Human Rights, Religious Conflict and Globalisation - Ultimate Voices in a New World Order," International Journal of Multicultural Studies, Vol. 1, No. 1, (1999): pp. 2-19.

53 O. Riis, "Modes of Religious Pluralism under Conditions of Globalisation," International Journal of Multicultural Studies, Vol. 1, No. 1, (1999): pp. 20-34.

${ }^{54}$ For an overview of theoretical literature on religious pluralism see M. Chaves and P. Gorski, "Religious Pluralism and Religious Participation," Annual Review of Sociology, Vol. 27 (2003): pp. 261-281. 
that there are many religions and few societies in which there is only a single religion. These are facts and have been for as long as there have been religions in the case of internal pluralism and for many centuries in the case of external pluralism. They are also not going to change. Pluralism is a given. In the twenty-first century pluralism presents new challenges and opportunities because more people know more about "other religions" than they did in the past and globalization has led to the distribution of all major religions across the planet. The United States, for example, has gone from being an overwhelmingly Christian nation to being the world's most religiously diverse society. ${ }^{55}$ A century ago it was possible for someone from my village to know almost nothing about external pluralism. People knew that there were different sorts of Christians, and perhaps had very vague, and usually entirely inaccurate, ideas about strange people called Jews and "Mohammadans." None of them would have known about Buddhists or Hindus, let alone Sikhs. Even when I was growing up in that village in the 1950s, I had never met people who were not Christians and certainly did not think about them very much. There are villages in Indonesia that, in this respect, are very similar to my own and many Indonesians with life experiences similar to my own.

The world has changed in very basic ways. It is now almost impossible not to know about people of other religions, even if you have never met one. This is one of the facts of Globalization. It is not going away. There is no going back. We have no choice other than to deal with pluralism, but we do have a choice about how we deal with it. Internal pluralism is also a fact. It is not going to disappear. History teaches us that there will always be people that will try to make it disappear by some combination of persuasion and force. History also teaches us that they will fail.

If we have no choice other than to deal with pluralism, it makes sense to understand it, so that we can make better and more productive choices in dealing with internal and external "religious others." This is where Religious Studies, and in those parts of the world where there are large Muslim populations, Islamic Studies, are important. They do not always point towards solutions to social, religious or political problems, but they do provide people with the

55 R. Wuthnow, America and the Challenges of Religious Diversity (Princeton: Princeton University Press, 2005). 
kinds of information and knowledge they need to make difficult choices and hopefully can help to counter misinformation and rumors that often circulate in social context combining pluralism and ignorance.

Professor Diana Eck, President of the American Academy of Religion, and a long time scholar of Hinduism in India and more recently religious pluralism in the United States, has recently identified three dimensions of the challenges and opportunities of pluralism. ${ }^{56}$ These are pluralism as a civic issue, pluralism as a theological issue, and pluralism as an academic issue. While I am in agreement with most of what she has written, my own experience teaching, conducting research and living in Indonesia gives me a somewhat different perspective.

Pluralism as a Civic Issue also means pluralism as a political issue at local, national and trans-national levels. The basic choice here would seem to be that between accepting pluralism as a fact of life or fighting it. It is possible to fight pluralism at a local level and actually win. Ethno-religious "cleansing" and genocide are strategies for dealing with pluralism that have been employed all too often. It is possible to make life so difficult for people of "other" religions that they leave the community, go underground or--you can kill them. None of these are pleasant, they are morally repugnant and they are dangerous, because violence almost always breeds counter-violence as Stanley Tambiah's masterful studies of religious violence in India have shown so clearly. ${ }^{57}$ It is possible to fight pluralism at the national and trans-national levels. This is a fight that cannot be won. Some Americans are afraid of Muslims, so much so that they think our new president actually is one. Some Indonesians are afraid of Christians. Barack Obama is not a Muslim but millions of Americans are. There are millions of Christians in Indonesia. This is not going to change. Because we cannot win a fight against pluralism, and should not fight it in the first place, we must conquer fear of it. We do not have to embrace it. We do not have

\footnotetext{
${ }^{56}$ D. Eck, "Prospects for Pluralism: Voice and Vision in the Study of Religion," Journal of the American Academy of Religion, Vol. 75, No. 4 (2008): pp. 743-776.

${ }^{57}$ S. Tambiah, Leveling Crowds; Ethnonationalist Conflicts and Collective Violence in South Asia (Berkeley: University of California Press, 1996). On religious violence in Indonesia see M. Woodward, "Religious Conflict and the Globalization of Knowledge: Indonesia 1978-2004," in L. Cady and S Simon (eds.), Religion and Conflict in South and Southeast Asia. Disruption Violence (London: Routledge, 2006).
} 
to accept the theologically questionable proposition that all religions are really the same. Nor is it reasonable to expect that efforts to convince millions of people to change their religions will prove to be successful. We have no choice other than to live with pluralism, so our best choice is to learn enough to live without fear. The same is true at the trans-national or global level. To put it bluntly, history teaches us that Crusades and Jihads do not work. Many people are killed, injured or driven from their homes, vast amounts of money are wasted and the religious composition and orientation of the global community changes very little. Rational choice theorists have taught us that individual and collective self interests are among the most powerful forces motivating human behavior. Accepting pluralism is a rational choice. It is clearly in the interest of all parties when these issues are understood. Unfortunately, inaccurate understanding of religious others often fosters misunderstanding of what self interest and rationality actually are. The demonization of others, portraying them in terms of archetypes of evil and in terms of what we fear most is among the defining features of religious conflict. ${ }^{58}$ It is here that Islamic and Religious Studies can make real contribution to the resolution of potentially deadly conflicts. It does not require great erudition to rebut the portrayals of religious others as inherently evil and dangerous. It does require courage.

Pluralism as a Theological Issue is more difficult, but no less important. The question that religious scholars, of all religions, must confront is that of: "If a particular religion is TRUE, why are there others?" Some religions, including Islam, are willing to accept theological pluralism to some degree. The Qur'anic teachings concerning "People of the Book" are among the clearest examples of theological pluralism. Mystical variants of most religions are more likely than others to accept and even to embrace theological pluralism. For many, however, there is no good answer to this question. And there does not have to people for people to live and work together in relative peace and harmony. A few years ago I was discussing this issue with people at the offices of Dean Dakwah Islamiyah Indonesia in Jakarta. When the topic turned to working together with Christians, and even Jews, one young man explained; "Oh, we can work with them together in this world, they are all going to hell in the next, but for now that

${ }^{58}$ See Woodward, "Religious Conflict and the Globalization of Knowledge." 
does not matter." He then cited a Hadi according to which, this world is hell for the believer and heaven for those who do not believe. I know that some people will find this solution to the problem of theological pluralism unacceptable. Speaking as a Muslim I find it theologically unacceptable - but it is at least better than the alternative of thinking that there is a religious obligation to fight and kill the "religious other." The point I am trying to make is that even if we can not arrive at an optimal, or even good solution to the theological challenge of pluralism, which would be the best of all possible worlds, we can certainly work towards avoiding the worst of all possible worlds. Tariq Ramadan put it eloquently when he called for the imagination of a "new we" in which people of all religions, and those of no religion, work together to solve the problems of this world in reasonable ways and without regard for religious differences. ${ }^{59}$ Put another ways, the problems of dunia are exactly that and while we may ultimately be more concerned with akhirat those issues need not stand in the way of working to build better lives for our children and grandchildren.

Pluralism as an Academic Issue confronts all of us who are teachers or students of religion at any of Indonesia's STAIN, IAIN and UIN, or at The Center for Religious and Cross-cultural Studies at Gadjah Mada University or in the Religious Studies Department at Arizona State University or in thousands of other similar institutions around the globe. All of us teach and/or study particular and often very specialized subjects. I teach, among other things, World Religions and Religion and Violence. It would not be responsible to turn out classes into political arenas. We have subjects that we must teach and must continue to do so to the very best of our abilities. But, I think, we should keep these issues in mind and in whatever ways we can seek to instill at the very least values based on pragmatic tolerance if not pluralism in our students. We do more than teach. Most of us conduct research and write as well. Again, many of us have very specialized agendas that we must remain true to. But some of us, at least, need to think and write about the challenges and opportunities of pluralism even if we do consider them to be only affairs of this world (dunia). Methodologically it is also essential that if we employ techniques that

${ }^{59}$ T. Ramadan, Western Muslims and the Future of Islam (New York: Oxford University Press, 2006). 
implicitly or explicitly employ concepts that are derived from religious traditions that we be open to the possibility that religions other than our own can contribute to the development of comparative methodologies. We must also make it clear when we are speaking in academic voices and when we speak in religious voices.

There are scholars, most of them writing from the perspective of particular religions or from what I have referred to as transconfessional religious thought, who seek deeper religious solutions to the challenges of theological pluralism and who find religious inspiration and opportunities in pluralism. Among these is the hope that by understanding something of other people's religions that we can come to a deeper and richer understanding of our own. This may be too much to ask from most people, but there are some who would for this goal.

\section{Conclusions}

Professor Eck closes her discussion of religious pluralism with the observation that:

Creating pluralist societies, whether in the United States or Indonesia, will require the energies of citizens who participate in the forms of public life, and civic bridgebuilding that make diverse societies work. Generating new thinking adequate for the twenty-first century and its religious life will also require the best of theological reflection in every religious tradition, new theological thinking that is responsive to the challenges of both secularism and religious pluralism.

To this I would add only that new thinking is required not only from theologians, but from those of us engaged in other aspects of Religious Studies and Islamic Studies as well. God Knows Best. []

\section{Bibliography}

\section{Books and Articles}

Alatas, F. "Contemporary Muslim Revival: The Case of 'Protestant' Islam.” The Muslim World. Vol. 97 (July 2007).

Al-Insan Journal Kajian Islam. Vol. 1, No.1 (2007).

Bellah, R. Beyond Belief: Essays on Religion in a Post-Traditional World. NY: Harper \& Row, 1970. 
Benda, Harry J. "Christiaan Snouck Hurgronje and the Foundations of Dutch Islamic Policy in Indonesia." in Continuity and Change in Southeast Asia: Collected Journal Articles of Harry J. Benda. New Haven: Yale University Center for Southeast Asian Studies, 1972.

Berger, P. the Sacred Canopy: Elements of a Sociological Theory of Religion. Garden City, NY: 1967.

Chaves M. and P. Gorski. "Religious Pluralism and Religious Participation.” Annual Review of Sociology. Vol. 27 (2003): pp. 261281.

Chittick, W. The Sufi Path of Knowledge: Ibn al-Arabi's Metaphysics of Imagination. Albany: State University of New York Press, 1989.

Corsi, Pietro. Science and Religion. Baden Powell and the Anglican Debate, 1800-1860. Cambridge: Cambridge University Press, 1988.

Eck, D. "Prospects for Pluralism: Voice and Vision in the Study of Religion." Journal of the American Academy of Religion. Vol. 75, No. 4 (2008): pp. 743-776.

Eliade, M. The Myth of Eternal Return or Cosmos and History. Princeton: Princeton University Press, 1954.

Fitzgerald, Timothy. The Ideology of Religious Studies. Oxford: Oxford University Press, 2000.

Gaede, S. "Review Symposium: Peter L. Berger's 'The Heretical Imperative'." Journal for the Scientific Study of Religion. Vol. 20 (1981): pp. 181-185.

Gascoigne, J. Cambridge in the Age of the Enligbtenment: Science, Religion and Politics from the Restoration to the French Revolution. Cambridge: Cambridge University Press, 1989.

Geertz, Clifford. After the Fact: Two Countries, Four Decades, One Anthropologist, Cambridge: Harvard University Press, 1995.

-------. The Religion of Java. Glencoe: the Free Press, 1960.

Hanafi, H. "Pembaruan Wacana Keagamaan: Mulai dari Realita, Baru Teks." in M. Arkoun and Others. Orientalism vis-a-vis Oksidentalisme. Jakarta: Pustaka Firdaus, 2008.

Hodges, H. the Philosophy, of Wilhem Dilthey. Westport: Greenwood Press, 1952. 
Hurgronje, C. Snouck. Mekeka in the Latter Part of the Nineteenth Century. Leiden: E. J. Brill, 1931.

---------. Mohammedanism. New York: the Knickerbocker Press, 1916.

---------. The Achenese. Leiden: E.J. Brill, 1906.

James, William. V arieties of Religious Experience. New York: Collier, 1961.

Jantzrace, M. "For an Engaged Reading: William James and the Varieties of Postmodern Religious Experience." in Jeremy Carrette (ed.). William James and the V arieties of Religious Experience: A Centenary Celebration. London: Routledge, 2005.

King, R. Orientalism and Religion: Post Colonial Theory and the Mystic East. London: Routledge, 1999.

Kuhn, T. The Structure of Scientific Revolutions. Chicago: University of Chicago Press, 1996.

Lamberth, D. "Conclusion: Experience and the Value of Religion Overview and Analysis." in Jeremy Carrette (ed.). William James and the Varieties of Religious Experience: A Centenary Celebration. London: Routledge, 2005.

Lewis, B. What Went Wrong? the Clash Between Islam and Modernity in the Middle East. New York: Harper Perennial, 2003.

McCalla, Authur. "When is History not History?." in Historical Reflections. 20 (1994): pp. 435-52.

McCutchen, Russell. Manufacturing Religion: The Discourse on Sui Generis Religion and the Politics of Nostalgia. Oxford: Oxford University Press, 1997.

Meuleman J. (ed.). Islam in the Era of Globalization. Muslim Attitudes Towards Modernity and Identity. London: Rutledge Curzon, 2002.

Nakamura, M. The Cresent Arises Over the Banyan Tree. Yogyakarta: Gadjah Mada University Press, 1983.

Nicholson, R. The Mystics of Islam: An Introduction to Sufism. London: Routledge and Paul, 1975.

Panjimas. Vol. 1, No. 12 (May 2007).

Pipes, D. Militant Islam Reaches America. New York: W.W. Norton, 2003. 
Polanyi, Michael and Harry Prosch. Meaning. Chicago: The University of Chicago Press, 1975.

Poloma, M. "The Sociological Context of Religious Experience." in Ralph W. Hood, Jr. (ed.). Handbook of Religious Experience. Birmingham: 1995.

Popper, K. The Logic of Scientific Discovery. New York: Routledge, 2002.

Porpora, D. "Methodological Atheism, Methodological Agnosticism and Religious Experience." Journal for the Theory of Social Behavior. 36 (2006): pp. 57-75.

Post, S. Human Nature and the Freedom of Public Religious Expression. Notre Dame: University of Notre Dame Press, 2003.

Powell, Baden B. H. Creation and its Records. A Brief Statement of Christian Belief with Reference to Modern Facts and Ancient Scripture. London: Hodder and Stoughton, 1886.

Preus, Samuel. Explaining Religion: Criticism and Theory from Bodin to Freud. New Haven: Yale University Press, 1987.

Pritchard, E. Evans-. Nuer Religion. London: Oxford University Press, 1956.

Ramadan, T. Western Muslims and the Future of Islam. New York: Oxford University Press, 2006.

Ricklefs, M. Jogjakarta under Sultan Mangkubumi, 1749-1792: A History of the Division of Java. London: Oxford University Press, 1974.

Riis, O. "Modes of Religious Pluralism under Conditions of Globalisation." International Journal of Multicultural Studies. Vol. 1, No. 1 (1999): pp. 20-34.

Said, E. Orientalism. New York: Vintage Books, 1979.

Schleiermacher, F. On Religion: Speeches to Its Cultured Despisers, translated by John Oman. Louisville: Westminster John Knox Press, 1994.

Smith, C. "Why Christianity Works: An Emotions-Focused Phenomenological Account." Sociology of Religion. Vol. 68 (2007): pp. 65-178.

Spickard, J. "Human Rights, Religious Conflict and GlobalisationUltimate Voices in a New World Order." International Journal of Multicultural Studies. Vol.1, No. 1 (1999): pp. 2-19. 
Steenbrink, K. Dutch Colonialism and Indonesian Islam: Contacts and Conflicts 1596-1950. Amsterdam and Atlanta: Editions Rodopi B.V., 1993.

Tambiah, S. Leveling Crowds: Ethnonationalist, Conflicts and Collective Violence in South Asia. Berkeley: University of California Press, 1996.

Thomas, Kuhn. The Copernican Revolution: Planetary Astronomy in the Development of Western Thought. Cambridge: Harvard University Press, 1957.

Tomoko, Masuzawa. The Invention of World Religions. Chicago: University of Chicago Press, 2005.

W. Roff, "Islam Obscured? Some Reflections on Studies of Islam and Society in Southeast Asia." Archipel. 29, 1 (1985): pp. 7-34.

Welch, C. Protestant Thought in the Nineteenth Century. New Haven and London: Yale University Press, 1972.

Wieber, Donald. The Politics of Religious Studies. New York: Palgrave, 1999.

Woodward, M. "Order and Meaning in the Yogyakarta Kraton." in S. Russell and L. Aragon (eds.). Structuralism's Transformations: Order and Revision in Indonesian and Malaysian Societies. Tempe: ASU PSEAS Monograph Series, 2000.

--------. "Religious Conflict and the Globalization of Knowledge: Indonesia 1978-2004." in L. Cady and S. Simon (eds.). Religion and Conflict in South and Southeast Asia: Disruption Violence. London: Routledge, 2006.

--------. Islam Jawa Kesalehan Normatif Versus Kebatinan. Yogyakarta: LKiS, 1999. (fourth edition 2008).

---------. Islam, Nationality and Culture. Yogyakarta: Universitas Islam Negeri Sunan Kalijaga Press, forthcoming.

---------. Jalan Baru Islam: Memetakan Paradigma Mutakhir Islam Indonesia. Jakarta: Mizan, 1998.

Wuthnow, R. America and the Challenges of Religious Diversity. Princeton: Princeton University Press, 2005.

Yamane, D. "Narrative and Religious Experience." Sociology of Religion. 61 (2000): pp.171-189. 